Vol 1, pp 70-83, April 2017 - ISSN 2561-1666

\title{
The Meaning of Home for Aging Women Living Alone in North Eastern Ontario
}

\author{
A. Barry, R. Heale, A. Marise Lavoie, R. Pilon
}

A. Barry, RN, BScN, $\mathrm{MScN}$

School of Nursing

Laurentian University

ax_barry@1aurentian.ca

R. Heale, RN(EC), NP-PHC, DNP, PhD(c)

Associate Professor, School of Nursing

Laurentian University

rheale@laurentian.ca

A. Marise Lavoie, $\mathrm{RN}, \mathrm{PhD}$

Professor, School of Nursing

Laurentian University

amlavoie@laurentian.ca

Roger Pilon, NP-PHC, PhD

Assistant Professor, School of Nursing

Laurentian University

rpilon@laurentian.ca 
Diversity of Research in Health Journal / Revue de la Diversité de la Recherche en Santé Vol 1, pp 70-83, April 2017

\begin{abstract}
The experience and meaning of home for older, community dwelling women, who live alone was investigated. With the older demographic expanding and resources being directed at keeping older adults in their home, an expanded knowledge base is required. Interviews were conducted with seven home dwelling older women. Semi structured questions targeted the meaning of home for the participants. The theme of precariousness dominated the findings, including precariousness of formal and informal care, precariousness of winter and that home is not precarious. The study confirms that home is the preferred location for aging women. Health policy and services should continue to be implemented to accommodate this preference. Future research is needed to confirm the findings with a larger sample, incorporating additional life circumstances and to investigate the impact of factors such as winter weather and financial vulnerability on women's ability to remain at home as they age. (145 words)
\end{abstract}

Keywords: concept analysis, nursing, aging in place, home, older adults, women, evolutionary, community care, geriatric, older adult.

\title{
Résumé
}

Ce projet de recherche explore les dimensions affectives et expérientielles chez les femmes quant à leur situation résidentielle lors du vieillissement. Alors que notre société fait face à l'accroissement de leur démographique et que les ressources gouvernementales sont davantage investies afin de leur permettre de rester chez soi; le besoin d'établir des données concrètes à ce sujet émergent. Des questions semi-dirigées visaient à évaluer la valeur du concept $\mathrm{du}$ 'chez-soi' auprès des participantes. Le thème de la précarité fut le thème dominant qui est ressorti dans les résultats; à la fois relié aux soins de santé formels et informels, à l'hiver et tout ce qu'il entraîne et finalement au soulignement du fait que pour elles demeurer à domicile élimine la précarité. Cette étude confirme hors de tout doute que les femmes préfèrent vieillir à domicile. Les politiques et les services en matière de santé devraient donc continuer à être mis en œuvre afin d'accommoder cette préférence. Un besoin existe pour des recherches plus avancées à ce niveau en ayant un échantillon plus vaste, en incorporant des variables environnementales additionnelles et en explorant l'impact de facteurs tels le climat hivernal et la vulnérabilité financière de ce groupe démographique en ce qui a trait à leur habileté de demeurer à domicile au fur et à mesure qu'elles vieillissent.

Mots clés: analyse de concepts, infirmière, vieillissement en place, personnes âgées, femmes, évolutionniste, soins communautaires, gériatrique, adulte plus âgé. 
Diversity of Research in Health Journal / Revue de la Diversité de la Recherche en Santé Vol 1, pp 70-83, April 2017

\section{Introduction}

The aging demographic in Canada has resulted in the need to advocate for supportive communities, policies and health care systems to accommodate those aging at home (Ministry of Health and Long-Term Care, 2015; Sinha, 2012). Discussion about aging at home intensifies with the very old and, in particular, with women who live longer than men and are more likely to live their remaining years alone (Klinenberg, 2012; Statistics Canada, 2011). Aging and living alone has come to mean mounting vulnerabilities, fear, risk, loneliness, and isolation (Eshbaugh, 2008; Klinenberg, 2012, 2016; Victor, Scambler, Bond, \& Bowling, 2000). Women living longer and alone face an increase in chronic disease, a decrease in personal and financial resources, and often a decrease in informal care partner (Davidson, DiGiacomo, \& McGrath, 2011; Kinsella, 2000; Perrig-Chiello \& Hutchison, 2010).

The social and physical losses of advanced age mean that a great deal of effort must go into maintaining and sustaining the older adult in her home (Godfrey \& Townsend, 2008, Nicholson, Meyer, Flatley \& Holmes, 2012; Rioux, 2005). Risks include personal safety, loneliness and isolation, challenges with preparing food, and difficulties with home maintenance (Eshbaugh, 2008; Hinck, 2004; Löfqvist et al., 2013; Porter, 2007; Sixsmith et al., 2014). For formal care providers and family members these risks trigger concerns about safety that may result in the call for relocation (Golant, 2008; Klinenberg, 2012; Michael \& Yen, 2014). Given this evidence, it has been argued that home is not always the place where the best care is received and may in fact pose a safety risk (Golant, 2008).

Despite concerns, home is a place which bears a unique importance to older women who often consider remaining in their home as worth the risk (Birkeland \& Natvig, 2009; Bornat \& Bytheway 2010). Older women spend more time in their homes than their younger counterparts and are tied to their dwellings through attachments to memories, family, autonomy, routine, and access to community (Hidalgo \& Hernandez, 2001; Oswald \& Wahl, 2005; Roin, 2015; Rollero \& Pilloli 2010). Living alone at home allows for autonomy, personal preference, memories and connections to family, while relocation is associated with separation from family and community, the loss of independence, and a resulting decline in health and well-being (Bernoth, Dietsch, \& Davis, 2012; Davies, 2012; Hinck, 2004; Löfqvist et al., 2013; Saunders \& Heliku, 2008; Sixsmith et al., 2014). Home has come to symbolize recovery from illness and is often seen to facilitate health because of the independence and resources home offers (Fänge \& Ivanhoff, 2009; Godfrey \& Townsend, 2008). In fact, home is not synonymous with isolation and loneliness (Eshbaugh, 2008; Hinck, 2004).

Portacolone $(2013,2015)$ explored the balance between the risks and benefits of home through the concept of precariousness within individual resources, service provision and societal emphasis on independence. The vulnerabilities that are represented in these factors are of great importance in understanding the experience of aging and living alone.

If women are to successfully age at home, the associated risks will have to be mitigated through health care services that are appropriate, relevant, and sustainable (Klinenberg, Torres, \& Portacalone, 2013; Sinha 2012). However, a foundational gap of knowledge, specifically the meaning of home, must be explored prior to the development of services. The aim of this study was to explore the meaning of home for older, community dwelling women who live alone and to review the findings with respect to health care policy. 
Diversity of Research in Health Journal / Revue de la Diversité de la Recherche en Santé Vol 1, pp 70-83, April 2017

\section{Methods}

This was a qualitative study using interpretive description methodology. Ethical approval for this study was received from Laurentian University's research ethics board.

\section{Sample}

Purposive sampling was undertaken (Thorne, 2008). Inclusion criteria were women greater than 80 years, living alone in a northeastern Ontario city, English speaking with no diagnosis of dementia. After numerous difficulties, a local church supported the study and seven participants were recruited. Despite the small sample size, there were enough participants to provide meaningful description and bring forth an understanding of this complex problem (Thorne, 2008).

\section{Data Collection}

The primary data collection technique consisted of individual interviews in the participants' homes (approximately 60 to 120 minutes in length). The interviews were guided by semi-structured, open-ended questions. Observation of their homes and surrounding, along with literature and health policy documents, were also considered data in this study (Thorne, 2008).

\section{Data Analysis}

Data collection and analysis occurred concurrently (Thorne 2008). The data, including interview transcriptions and field notes, were reviewed several times in order to develop a sense of the whole, to become aware of shifts in meaning, and to note and categorize sensitizing concepts. To facilitate this approach, marginal memos were an initial technique used and through this process themes and patterns emerged (Giorgi \& Giorgi, 2003; Thorne, 2008).

Under emerging themes, larger units of data were used as codes to gather data with similar properties and avoid excessive precision (Thorne, 2008). From here, questions were asked of the data by using coding and memos in different ways (Miles, Huberman, \& Saldana, 2014). Possible relationships were explored using schematics or network diagrams (Miles et al., 2014). Finally, results were taken back to the transcripts to ensure the findings remained true to the participants.

\section{Results}

\section{The Precariousness of Formal Institutions}

The main finding of this study was not specifically related to the participants' view of their home. Rather, when the participants were asked if the experience of home had changed as they aged and transitioned to living alone, and what they believed would not be home, they shared stories of health challenges, experiences with vulnerability, and experiences with healthcare institutions. Interestingly the contact with formal healthcare institutions influenced their meaning of home.

Changes in health and function experienced by the participants and their peers resulted in increased involvement with formal institutions. Their encounters included unplanned stays (both short and longer term), planned visits, and shared experiences with friends who relocated. 
Diversity of Research in Health Journal / Revue de la Diversité de la Recherche en Santé Vol 1, pp 70-83, April 2017

Participants brought to light that the precariousness of formal care often overshadowed the precariousness of home and any uncertainty or loss home may represent, thus emphasizing the resources home offered and strengthening their attachment to home. In short, formal healthcare institutions increase place attachment and in this way shaped the meaning of home to them.

\section{Busyness of Formal Care}

Hospitals, assisted living facilities, long term care homes and rehabilitation facilities are institutions abuzz with patients/ residents and staff. The busyness of these institutions was commented on by participants and it was highlighted that these organizations offered overstimulation and no way to avoid it. This busyness and institutional overstimulation has been noted by other researchers and labelled a lack of privacy (Jacelon, 2003).

"like when I visit friends in some of the nursing homes...it's very busy... with the nurses all around and people coming in to see what you're doing, and there's other patients. So, it's nice to be [home] where I can be on my own... It's just too noisy and too busy... (P\#1).

I have noticed things since I've been here [in the assisted living facility]. That people are, --their rooms are just FULL of furniture. ...... (P\#7)

\section{Unmet Needs in Formal Care.}

The precariousness of formal institutions also surfaced in terms of participants needs not being met.

"knee surgery was fine, the aftercare was not. They left me 3 hours in a chair, sitting,... and that swelled my knee up and I couldn't stand up and I kept buzzing and they didn't come..." (P\#3)

I just missed the view and being close to my family-They came every day to see me, but they would only stay 10-15 minutes or something. (P\#1)

The unmet needs in formal care institutions increased attachment to home and emphasized the resources home offers. Home was seen as a place where needs were met and healing occurred.

"it's a good feeling to be home, I think you get better a lot faster, because you are in your own surroundings" (P\#3).

Many participants had built their own homes, and modified them to accommodate their interests, their changing function, and the needs of their family. For example, home accommodated a love of gardening and nature, acted as a base for family, and represented a symbol of a lifetime of accomplishments and independence. 
Diversity of Research in Health Journal / Revue de la Diversité de la Recherche en Santé Vol 1, pp 70-83, April 2017

\section{Threats to Well-Being in Formal Care.}

Some experiences with formal institutions went beyond unmet needs and were interpreted as threats to health and well-being. Threats to health were interpreted as separation from communities, exposure to dangerous people, isolation, and a lost sense of independence.

"stuff [in the institution]became an actual threat to my life. Someone ...mistook me for someone else...that drove my blood pressure up. They had to get me out of there." (P\#3)

These experiences of formal institutions as threatening served to emphasize the value of home. For participants home was almost universally described as safe and safety.

Further, formal institutional care could be precarious not just in terms of unmet needs, but as a place which was viewed as taking an active role in keeping participants from their home.

"So I had to prove I could be [home] alone, and do the work, and they helped me with all those tests...., and I passed them so I got home" (P\#1)

The women were well aware of the benefits of home:

Participant : I'd lose a lot, if I couldn't be here.

Researcher: What would you lose?

Participant: Well, I couldn't get to church without trouble, be involved, you know, more directly, having to talk to people that you know (P\#3)

\section{Loneliness in Formal Care.}

Despite widespread discussion in the literature that loneliness is a risk of aging alone at home, for participants loneliness was another element of precariousness associated with formal care.

"She went to an [assisted living facility] and she wasn't very happy there, because she found it lonely" (P\#1)

Conversely, many participants denied loneliness at home and for those that did discuss loneliness, they viewed the loneliness as transient. Participants engaged in activities to combat loneliness.

Lastly, institutions represented the antithesis of home.

Researcher: Can you tell me a bit about what is NOT home?

Participant: Hospital. Put[ting] me in a nursing home.. (P\#3)

Researcher: What is important to you about staying here?

Participant: What's important? Not to go in a home (long term care). And um, that's about it. (P\#4) 
Diversity of Research in Health Journal / Revue de la Diversité de la Recherche en Santé Vol 1, pp 70-83, April 2017

A number of participants were willing to consider relocation. They discussed it as a future occurrence, but gave consideration or discussed past consideration of moving to apartments, moving to be closer to family, or returning to their country of birth. Therefore, it would be hasty to assume home was only where they are now. For many it was the idea that to leave home was equated with institutions and these places were considered to have the least potential to be home.

\section{Precariousness of Informal Care}

Informal, unpaid care is care provided by family, friends, and faith groups. Informal care was present in the lives of all participants and was a great source of functional and social support. As such, it was valued and appreciated by participants. However, for some there was an element of precariousness between informal support and the experience of home. This precariousness took on several forms.

First, with families being geographically spread out, leaving home to be closer to the informal support of family outside of one's community was thought to be precarious.

[Friends] moved to a different city, and moved to where their children were. But I must say that none of them are very happy. Because they are older, and their children, you know, look after them. In a certain way, they see them every day, or even every week, I don't know, but they say that they just don't have any friends! And it's too hard to meet people. (P\#1)

The belief that leaving home to be closer to family was precarious served to increase the value of aging at home and reinforced the precariousness of leaving home.

For others, the lack of informal care to support the women introduced precariousness into aging at home. Many of the participants sought out, and paid for care services when informal unpaid care was not available.

And if you have a family or not, they are not always right next to you. They are at the other end of the country, and so you've got to...make up your mind-if you want to stay alone and struggle, or um... if you make it, that's a fact (P\#4)

Other widows, a lot of them don't have their family around; they are in British Columbia or Newfoundland, or the States. They always tell me how lucky I am to have ALL of my family here (P\#6)

For these participants, family's belief that home was no longer appropriate for the women served to reinforce the value of home as the suggestion of relocation prompted the women to consider and articulate their reasons for staying in their home.

As I said my daughter wants me to move out, and I don't want to go. (P\#2)

\section{Precariousness of Winter}

Winter added to the precariousness of living alone at home. Winter meant increased isolation, a risk for falls, less activity, and more difficulty with transportation. 
Diversity of Research in Health Journal / Revue de la Diversité de la Recherche en Santé Vol 1, pp 70-83, April 2017

I'm still planning on going away this winter, because I find the winters are difficult-it's icy, and it's hard to get out and I don't really feel comfortable driving in the snow (P\#1).

"[Falls] always in the winter on ice....And however careful you are on ice, you can't stop yourself" (P\#6)

"I didn't want to be having this long drive, especially in the winter, so we decided, if we wanted to be together, here, to move [into town]." (P\#5)

\section{Living Alone is Not Precarious}

Most participants were widows for varying lengths of time and one was never married and without children. However, living alone was not experienced as precarious. These women described a lifetime of skill development which gave them the abilities to live alone. As a group they had sought out and lived through many transitions, health challenges, and losses of loved ones. The women identified these events in their lives as giving them the abilities to live alone and manage the changes that accompanied aging at home alone. Active strategies, such as joining new groups, were used to adapt to losses. To accommodate the functional changes, the women accessed formal paid care for the home maintenance that their husbands were responsible for or for which they could no longer do. A number of participants described that it was not being alone that proved challenging and isolating, but the increasing functional changes associated with advanced age.

Researcher: After your husband passed away, and you had to live alone, were there challenges? Changes? Adjustments?

Participant: Well, there were...not right away, but now in the last 5 years (P\#6)

\section{Discussion}

This study confirms women prefer to age at home and that there is mistrust and concern related to institutionalized care. In fact, experiences with healthcare institutions influence the meaning of home for older women living alone. The precariousness of the experiences with these institutions strengthens attachments to home by reinforcing and bringing to light the benefits and resources home offers despite potential deconditioning and loss of function. Precariousness within the home includes the unique challenges presented by the provision of informal care and the winter conditions which are ever a part of the Canadian climate. These findings provide a foundation for discussion about, and development of, health care policy and programs that reflect the concerns of older women living alone. In particular, focus should be to provide supports to mitigate risks related to both their options for staying in their homes or transferring to formal care.

There are, indeed, reasons to be concerned about institutionalized care. Dobbs et al (2008) found that the ageism experienced by elders within long-term care facilities and assisted livings facilities made living within these institutions difficult, dehumanizing and infantilizing. Kayser-Jones (2002) went further and exposed that facilities do pose a threat to the health and well-being of older adults. Neglect is real and patients/residents are aware of the power formal caregivers can offer or withhold (Band -Winterstein, 2015; Dobbs et al, 2003; Forbes-Thompson 
Diversity of Research in Health Journal / Revue de la Diversité de la Recherche en Santé Vol 1, pp 70-83, April 2017

\& Gessert, 2006; Gustafsson, Heikkilä, Ekman, \& Ponzer, 2010). Social hierarchies and cliques exist in these facilities which exempt those with cognitive, physical and socioeconomic vulnerabilities (Dobbs et al, 2003; Nakrem, Vinsnes, \& Seim, 2011). When looking at hospitals, Jacelon's (2003) study of elders' hospital stay highlighted organizational customs which take away dignity from participants and the need to return home to restore dignity.

However, there is a strong likelihood that women will be involved in formal, institutionalized care at some point in their later lives. Formal care has its place, especially when informal home support is not available (Bacsu et al, 2012). Given the concerns, health organizations must continually plan and develop services to anticipate and meet the needs of their service populations. Each organization must foster a culture of quality improvement to make these institutions less precarious and more in line with the need to provide quality care in a home-like environment (King, 2004).

The women in this study viewed themselves as resourceful and autonomous, and as active participants in their care, whether formal or informal (Foster \& Neville, 2010; Petry; 2003; Porter, 2005). With family scattered over a wide geography the women actively organized paid formal and informal supports to meet their needs. Overwhelmingly these women had the financial resources to pay for formal care and it is unlikely all older women are able to do so (Arber, 2006). The need to pay for informal care demonstrates that the trend away from publicly funded home support has increased the burden on informal care partners, put the economically vulnerable at greater risk, and disproportionately affected older women (Davidson et al., 2011).

Homecare services are currently focused on curative physical care, rather than supportive care and mental health (Allan, Ball, \& Alston, 2007; Forbes, Stewart, Anderson, Parent, \& Janzen, 2003; Markle-Reid et al., 2008). In contrast, older women living alone typically require more non-medical supportive services to maintain functioning (Markle-Reid et al., 2008). These needs are more pronounced in winter when inclement weather results in reduced activity of older women, increase in home maintenance and increased concerns of family (Mirchandani et al., 2005). As our community demographics change, it will be important for health care providers and policy makers to capitalize on the strengths and resources of the elderly living at home. Recognition of the need to target resources toward assisting older women to remain at home including funding for non-medical support services and better community resources to offset the risks of living alone, including the added burden of winter weather.

\section{Limitations}

The participants studied were overwhelmingly widowed and this reflects the current majority. However, it is projected that with the passing of time there will be an increase in older women who live alone because of divorce or who identify themselves in a romantic relationship while choosing to live alone (Davidson, 2006). Furthermore, this study had only one participant who was never married and exploring the experience of home with additional women who have lived their life solo would be valuable. In addition, all participants were Caucasian. Although this is representative of this generation of women, in Sudbury, it certainly limits an understanding of non-Caucasian women. This is particularly relevant when one considers that Sudbury and Ontario are becoming increasingly ethnically diverse (Statistics Canada, 2015). Another point for consideration is childless elders. Two of the study participants were childless and this is expected to increase and represent a group of women with less informal supports and possibly, more financial vulnerability (De Medeiros et al. 2013). 
Diversity of Research in Health Journal / Revue de la Diversité de la Recherche en Santé Vol 1, pp 70-83, April 2017

\section{Further Research}

There would be value in exploring the findings of this study further including the meaning of home with women who had never married or partnered, childless women and those with financial vulnerabilities. A second path would be to further explore the concept of precariousness. Investigating precariousness would support mid and high level theory development, where concepts can be understood relative to each other for a greater understanding of the phenomenon (Morse, 2004; 2012).

\section{Conclusions}

This interpretive description study was undertaken to further explore the phenomenon of home among older women living alone and apply this understanding to health and healthcare. The main finding of the study is that contact with the institutions developed to care for older women strengthens their attachment to home. The study findings, that institutional care is precarious, support current endeavors to restructure and improve quality among home and community care, and the institutions caring for older women (Koren, 2010). However, it has been argued that research is currently skewed towards the knowledge of health providers, quantitative data, and researchers and this limits an understanding of problems and subsequently limits ways to solve problems (O'Grady, 2012). From this perspective, the study findings have the potential to complement the current understanding of aging at home by grounding the understanding of aging at home and institutional care in the everyday experience of the older woman. The findings from this study have added to the meaning of home and have allowed for a greater understanding of why women age in place and challenge beliefs that institutional care is a better alternative. The study advocates for ongoing change and quality improvement in healthcare institutions, home and community care, and professional practice.

\section{References}

Allan, J., Ball, P., Alston, M. (2007). Developing sustainable models of rural health care: A community development approach. Rural and Remote Health, 7(818). Available from: http://www.rrh.org.au

Arber, S. (2006). Gender and later life: Change, choice and constraints. In Vincent, J., Phillipson, C., \& Downs, M. (eds.), The futures of old age (54-61). London: Sage Publications.

Bacsu, J., Jeffery, B., Johnson, S., Martz, D., Novik, N., \& Abonyi, S. (2012). Healthy aging in place: Supporting rural seniors' health needs. Online Journal of rural Nursing and Health Care, 12 (21), 77-87.Available: http://www.rno.org/journal/

Baltes, P. \& Smith, J. (2003). New frontiers in the future of aging: From successful aging of the young old to the dilemmas of the fourth age. Gerontology, 49, 123-135. doi: $10.1159 / 000067946$

Band-Winterstein, T. (2015). Health care provision for older persons: The interplay between ageism and elder neglect. Journal of Applied Gerontology, 34(3), NP113 -NP127. doi: $10.1177 / 0733464812475308$

Birkland, A., \& Natvig, G. (2009). Coping with ageing and failing health: A qualitative study among elderly living alone. International Journal of Nursing Practice, 15, 257-264. doi:10.1111/j.1440-172X.2009.01754.X 
Diversity of Research in Health Journal / Revue de la Diversité de la Recherche en Santé Vol 1, pp 70-83, April 2017

Bornat, J., \& Bytheway, B. (2010). Perceptions and presentations of living with everyday risk in later life. British Journal of Social Work, 40, 1118-1134. doi:10.1093/bjsw/bcq001

Craciun, C., \& Flick, U. (2014). "I will never be the granny with rosy cheeks": Perceptions of aging in precarious and financially secure middle-aged Germans. Journal of Aging Studies, 29, 78-87. doi: dx.doi.org/10.1016/j.jaging.2014.01.003

Craciun, C., Gellert, P., \& Flick, U. (2015). Aging in precarious times: Positive views on aging in middle-aged Germans with secure and insecure pension plans. Aging International, 40, 201-218. doi: 10.1007/s12126-015-9223-5

Davidson, K. (2006). Flying solo in old age: Widowed and divorced man and women in later life. In Vincent, J., Phillipson, C., \& Downs, M. (eds.), The futures of old age (172179). London: Sage Publications.

Davidson, P., DiGiacomo, M., \& McGrath., S. (2011). The feminization of aging: how will this impact on health outcomes \& services? Health Care for Women International, 32, 10311045. doi: 10.1080/07399332.2011.610539

De Medeiros, K., Rubinstein, R., Onyike, C., Johnston, D., baker, A., McNabney, M., Lyketsos, C., Rosenblatt, A., \& Samus, Q. (2013). Childless elders in assisted living: findings from the Maryland assisted living study. Journal of Housing for the Elderly, 27. 206220. doi: 10.1080/02763893.2012.754823

Dobbs, D., Eckert, J.K., Rubinstein, B., Keimig, L., Clark, L., Frankowski, A., \& Zimmerman, S. (2008). An ethnographic study of stigma and ageism in residential care or assisted living. The Gerontologist, 48 (4), 517-526. doi: 10.1093/geront/48.517

Eshbaugh, E. (2008). Perceptions of living alone among older adult women. Journal of Community Health Nursing, 25, 125-137. doi: 10.1080/07370010802221685

Einstein, G. \& Shildrick, M. (2009). The post conventional body: Retheorising women's health. Social Science \& Medicine, 69, 293-300. doi:10.1016/j.socscimed.2009.04.027

Fänge, A. \& Ivanoff, S. (2009). The home is the hub of health in very old age: Findings from the ENABLE-AGE project. Archives of Gerontology and Geriatrics, 48, 340-345. doi:10.1016/j.archger.2008.02.015

Fernandes, N., \& Spencer, B. (2010). The private cost of long-term care in Canada: Where you live matters. Canadian Journal on Aging, 29(3), 307-316. doi:10.1017/S0714980810000346

Forbes-Thompson, S. \& Gessert, C. (2006). Nursing homes and suffering: Part of the problem or part of the solution? The Journal of Applied Gerontology, 25 (3), 234-251. doi: $10.1177 / 0733464806288561$

Forbes, S. \& Hoffart, N. (1998). Elders' decision making regarding use of long-term care services: A precarious balance. Qualitative Health Research, 8(6), 736-750. doi: $\underline{10.1177 / 104973239800800602}$

Foster, P. \& Neville, S. (2010). Women over the age of 85 years who live alone: A descriptive study. Nursing Praxis in New Zealand, 26(1), 4-13.

Giorgi, A., \& Giorgi, B. (2003). The descriptive phenomenological psychological method. In Camic, P., Rhodes, J., \& Yardley, L. (Eds.), Qualitative Research in Psychology: Expanding perspective in methodology and design (pp. 243-273). Washington, DC: American Psychological Association.

Godfrey, M., \& Townsend, J. (2008). Older people in transition from illness to health: Trajectories of recovery. Qualitative Health Research, 18(7), 939-951. doi: $\underline{10.1177 / 1049732308318038}$ 
Diversity of Research in Health Journal / Revue de la Diversité de la Recherche en Santé

Vol 1, pp 70-83, April 2017

Golant, S. (2008). Commentary: Irrational exuberance for the aging in place of vulnerable lowincome older adults. Journal of Aging \& Social Policy, 20(4), 379-397. doi:10.1080/08959420802131437

Gustafsson,B., Heikkila, K., Ekman, S.\& Ponzer, S. (2010). In the hands of formal carers: Older patients' experiences of care across the perioperative period for joint replacement surgery. International Journal of Orthopaedic and Trauma Nursing, 14(2), 96-108. doi:10.1016/j.ijotn.2010.01.002

Hidalgo, M. \& Hernandez, B. (2001). Place attachment: Conceptual and empirical questions. Journal of Environmental Psychology, 21, 273-281. doi:10.1006/jevp.2001.0221

Hinck, S. (2004). The lived experience of oldest-old rural adults. Qualitative Health Research, 14(6), 779-791. doi: 10.1177/1049732304265774

Jacelon, C. (2003). The dignity of elders in an acute care hospital., Qualitative Health Research,13(4), 543-556 doi: 10.1177/1049732302250762

Kayser-Jones, J. (2002). Malnutrition, dehydration, and starvation in the midst of plenty: The political impact of qualitative inquiry. Qualitative Health Research, 12(10) 1391-1405. doi: $10.1177 / 1049732302238750$

King, T. (2004). Status and standards of care for older adults: Despite regulatory, ethical and policy safeguards, the care of older adults is often suboptimal. With a lack of gerontological nursing education and an aging population, it's a situation that will only worsen unless changes occur now. The Canadian Nurse, 100(5), 23-26. http://search.proquest.com.librweb.laurentian.ca/docview/232084812?accountid=12005

Kinsella, K. (2000). Demographic dimensions of global aging. Journal of Family Issues, 21(5), 541-558. doi: 10.1177/019251300021005002

Klinenberg, E. (2012). Going solo. New York: The Penguin Press

Klinenberg, E. (2016). Social isolation, loneliness, and living alone: Identifying the risks for public health. American Journal of Public Health, 16(5), 786-787. doi: 10.2105/AJPH.2016.303166

Klinenberg, E., Torres, S., \& Portacalone, E. (2013). Aging alone in America. Council on Contemporary Families. Retrieved from https://www.contemporaryfamilies.org/wpcontent/uploads/2013/10/2012_Briefing_Klinenberg_Aging-alone-in-america.pdf

Koren, M. (2010). Person-centered care for nursing home residents: The culture change Movement. Health Affairs 29(2), 312-317. doi: 10.1377/hlthaff.2009.0966

Löfqvist, C., Granbom, M., Himmelsbach, I., Iwarsson, S., Oswald, F., \& Haak, M. (2013). Voices on relocation and aging in place in very old age-A complex and ambivalent matter. The Gerontologist, 53(6), 919-927. doi:10.1093/geront/gnt034

Markle-Reid, M., Browne, G., Weir, R., Gafni, A., Roberts, J., \& Henderson, S. (2008). Seniors at risk: the association between the six-month use of publicly funded home support services and quality of life and use of health services for older people. Canadian Journal on Aging, 27(2), 207-224. doi: 10.1353/cja.0.0025

Michael, Y, \& Yen, I. (2014). Aging and place-Neighborhoods and health in a world growing older. Journal of Aging and Health, 26(8), 1251-1260. doi: $10.1177 / 0898264314562148$

Miles, M., Huberman, A.M., \& Saldana, J. (2014). Qualitative data analysis: A methods sourcebook ( $3^{\text {rd }}$ ed.). Los Angeles: Sage

Ministry of Health and Long-term Care. (2015). Patients first: A roadmap to strengthen home and community care. Ottawa: Queen's Printer for Ontario. 
Diversity of Research in Health Journal / Revue de la Diversité de la Recherche en Santé

Vol 1, pp 70-83, April 2017

Mirchandani, S., Aharonoff, GB., Hiebert. R., Capla, EL., Zuckerman, JD., \& Koval, KJ. (2005). The effects of weather and seasonality on hip fracture incidence in older adults. Orthopedics, $28(2)$,

149-155. http://search.proquest.com.librweb.laurentian.ca/docview/203907393?accountid=12005

Morse, J. (2004). Constructing qualitatively derived theory: Concept construction and concept typologies. Qualitative Health Research, 14(10). 2004 1387-1395. doi: $10.1177 / 1049732304269676$

Morse, J. (2012). Qualitative health research: Creating a new discipline. Walnut Creek, California: Left Coast Press.

Nakrema, S., Vinsnes, A., \& Seimb, A. (2011). Residents' experiences of interpersonal factors in nursing home care: A qualitative study. International Journal of Nursing Studies, 48, 1357-1366. doi:10.1016/j.ijnurstu.2011.05.012

Nicholson, C., Meyer, J., Flatley, M., Holman, C., \& Lowtonk, K. (2012). Living on the margin: Understanding the experience of living and dying with frailty in old age. Social Science \& Medicine, 75, 1426-1432. doi.org/10.1016/j.socscimed.2012.06.011

O'Grady, L. (2012). What is knowledge and when should it be implemented? Journal of Evaluation in Clinical Practice, 18, 951-953. doi:10.1111/j.1365-2753.2012.01899.x

Oswald, F., \& Wahl, H. (2005). Dimensions of the meaning of home in later life. In G.D. Rowles \& H. Chaudhury (Eds.), Home and identity in late life (317-340). New York: Springer publishing Company.

Perrig-Chiello, P., \& Hutchinson, S. (2010). Health and well-being in old-age: The pertinence of a gender mainstreaming approach in research. Gerontology, 56, 208-213. doi: $\underline{10.1159 / 000235813}$

Petry, H. (2003). Aging happens: Experiences of Swiss women living alone. Journal of Women \& Aging, 15(4), 51-68. doi: 10.1300/J074v15n04_05

Portacalone, E. (2013). The notion of precariousness among older adults living alone in the U.S. Journal of Aging Studies, 27,166-174. http://dx.doi.org/10.1016/j.jaging.2013.01.001

Portacalone, E. (2015). Older Americans living alone: The influence of resources and intergenerational integration on inequality. Journal of Contemporary Ethnography, 44(3) 280-305. doi: 10.1177/0891241614528709

Porter, E. (2005). Older widows' experience of home care. Nursing Research, 54(5), 296-303.

Porter, E. (2007). Problems with preparing food reported by frail older women living alone at home. Advances in Nursing Science, 30(2), 159-174. doi: 10.1097/01.ANS.0000271106.42043.be

Punch, D. (2015). Where the heart is: Bold changes are on the horizon for home and community care in Ontario. Registered Nurse Journal, November/December 2015.

Rollero, C. \& Piccoli, N. (2010). Place attachment, identification, and environment perception: An empirical study. Journal of Environmental Psychology, 30, 198-205. doi:10.1016/j.jenvp.2009.12.003

Róin, Á. (2015). The multifaceted notion of home: Exploring the meaning of home among elderly people living in the Faroe Islands. Journal of Rural Studies, 39, 22-31. doi.org/10.1016/j.jrurstud.2015.03.002

Sinha, S. (2012). Living longer, living well: Recommendations to inform a seniors strategy for Ontario. Ontario: Queen's Printer for Ontario. 
Vol 1, pp 70-83, April 2017

Sixsmith J., Sixsmith, A., Fänge, A.M., Naumann, D., Kucsera, C., Tomsone, Haak, S. M., Dahlin-Ivanoff, S. \& Woolrych, R. (2014). Healthy ageing and home: The perspectives of very old people in five European countries. Social Science \& Medicine, 106, 1-9. doi.org/10.1016/j.socscimed.2014.01.006

Statistics Canada. (2011). Focus on geography series, 2011 census : Census metropolitan area of Greater Sudbury / Grand Sudbury, Ontario. Retrieved from http://www12.statcan.gc.ca/census-recensement/2011/as-sa/fogs-spg/Facts-cmaeng.cfm?Lang=eng\&GK=CMA\&GC=580

Statistics Canada. (2012). Tables by metropolitan area: Greater Sudbury. Retrieved from http://www.statcan.gc.ca/tables-tableaux/sum-som/101/met01/met106-eng.htm

Statistics Canada. (2015). Recent changes in demographic trends in Canada. Retrieved from http://www.statcan.gc.ca/daily-quotidien/151027/dq151027a-eng.pdf

Thorne, S. (2008). Interpretive description. Walnut Creek, California: Left Coast Press.

Victor, C., Scambler, S., Bond, J., \& Bowling, A. (2000). Being alone in later life: loneliness, social isolation and living alone. Reviews in Clinical Gerontology, 10 (4), 407-417. doi: $10.1017 / \mathrm{S} 0959259800104101$ 